\title{
Model Identifikasi Risiko dan Strategi Peningkatan Nilai Tambah pada Rantai Pasok Kelapa Sawit
}

\author{
Syarif Hidayat ${ }^{1 *}$, Marimin $^{2}$, Ani Suryani ${ }^{2}$, Sukardi $^{2}$, Mohamad Yani $^{2}$
}

\begin{abstract}
The actors in the palm oil supply chain industry are the farmers, traders, crude palm oil (CPO) factories, frying-oil factories (refineries), distributors and the consumers. The farmers sell fresh fruit bunches (FFB) to the CPO factories through traders. FFB is converted into CPO which is later sold to the refineries. Refineries convert CPO into frying oil which is sold to the consumers through the distributors. There are risks due to product quality consistency, price fluctuation and supply chain continuity. This study has two objectives: (1) to develop a model to identify, evaluate and rank the risks, (2) to develop a model to identify and rank the strategies in improving their added value. Data for this study was obtained through direct interviews and questionnaires. The respondents were selected experts and industry players. The data were processed using Fuzzy Analytic Hierarchy Process (FAHP) models. The first FAHP model showed that the two most important risks were the supply chain continuity and product quality. The second FAHP model showed that the recommended strategies to improve the added values of the actors were the improvement of the infrastructure/cluster development, followed by the usage of superior seeds and cultivation techniques.
\end{abstract}

Keywords: Supply chain, palm oil, risk, Fuzzy Analytic Hierarchy Process.

\section{Pendahuluan}

Rantai pasok atau supply chain adalah serangkaian kumpulan dari perusahaan yang saling tergantung secara berurutan dan bekerjasama dalam pengendalian, pengelolaan dan perbaikan arus barang, uang dan informasi dari sisi pemasok di hulu sampai ke sisi pengguna akhir (Preckel et al. [20]); van der Vorst [26]). Peran rantai pasok pada prinsipnya adalah untuk menambah nilai kepada produk, dengan cara memindahkannya dari suatu lokasi ke lokasi lain, atau dengan melakukan proses perubahan terhadapnya (Janvier-James [9]). Penambahan nilai tersebut dapat diterapkan pada aspek kualitas, biaya-biaya, saat pengiriman, fleksibilitas pengiriman dan inovasi (Trienekens [25]). Salah satu rantai pasok yang sangat penting di Indonesia adalah rantai pasok minyak kelapa sawit. Gambar 1 menunjukkan bahwa rantai pasok minyak kelapa sawit ini sangat penting karena nilai ekspor produk minyak sawit dan turunannya cenderung selalu meningkat (PKPN [19]). Pada tahun 2010 nilainya mencapai USD 15,6 milyar, berarti kenaikan sebesar 34,6\% terhadap tahun 2009, dan memberikan pajak bea keluar sebesar hampir US\$2,8 milyar (PKPN [19]).

\footnotetext{
1 Fakultas Teknologi Industri, Program Studi Teknik Industri, Universitas Al Azhar Indonesia, Jl. Sisingamangaraja Kompleks Masjid Agung, Kebayoran, Jakarta 12100. Email: syarif.hidayat@ uai.uaj.ac.id

2 Fakultas Teknologi Pertanian, Program Studi Teknik Industri Pertanian, Institut Pertanian Bogor, Dramaga, Bogor, 16680. Email: marimin@ipb.ac.id

* Penulis korespondensi
}

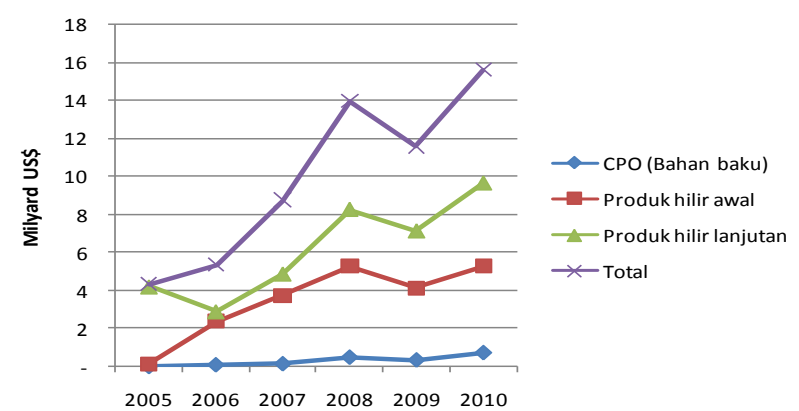

Gambar 1. Nilai ekspor minyak sawit Indonesia (PKPN [19])

Nilai ini berada pada urutan kedua setelah nilai ekspor produk non-migas Indonesia. Situasi monopsonistik di daerah-daerah menyebabkan kekuatan tawar petani masih lemah. CAO [2] melaporkan keprihatinan tentang produktifitas petani kecil yang rendah dan kesenjangan besar dalam keuntungan per hektar dibandingkan dengan perkebunan; kurangnya akses ke layanan keuangan dan teknis; dan kurangnya perwakilan yang memadai dalam perencanaan dan pengambilan keputusan di tingkat perusahaan perkebunan dan industri minyak sawit. Mulyana [18] menguraikan bahwa petani sawit menerima harga TBS yang rendah padahal menghadapi risiko lebih tinggi dibandingkan dengan pabrik CPO yang mempertahankan tingkat margin usahanya. Muncul kebutuhan untuk mengetahui apa saja jenis-jenis risiko dan bobot dampaknya kepada tiap pelaku rantai pasok dari kenyataankenyataan tersebut.

Tujuan penelitian ini adalah menghasilkan model untuk mengidentifikasi faktor-faktor risiko, meng- 
ukur tingkat kepentingan risiko, mendapatkan alternatif strategi untuk peningkatan nilai tambah, dan menentukan urutan prioritasnya. Ruang lingkup penelitian ini adalah rantai pasok minyak kelapa sawit yang mencakup petani sawit swadaya, pengepul, pabrik minyak kelapa sawit kasar (Palm Oil Mill), pabrik minyak goreng (refinery), distributor dan konsumen. Untuk mencapai tujuan tersebut dipergunakan beberapa teori, pendekatan dan model pendukung keputusan.

Teori-teori pertama yang akan digunakan adalah teori tentang risiko dan manajemen risiko. Holton [7] mendefinisikan risiko sebagai keadaan terpapar (exposure) kepada suatu kemungkinan kejadian yang tidak pasti. Risiko dapat juga didefinisikan sebagai adanya ketidakpastian tentang pencapaian sasaran perusahaan (Kaplan dan Garrick [10]). Manajemen risiko berhubungan dengan pengelolaan potensi-potensi risiko dengan cara mengidentifikasi, mengukur dan mengelola risiko-risiko tersebut (IRM, [8]). Risiko harus dikendalikan karena kalau tidak, akan ada peluang masalah pada pasokan bahan yang mengakibatkan kerugian finansial kepada perusahaan, Zsidisin et al. [29].

Model pendukung keputusan yang digunakan untuk penelitian ini adalah Fuzzy Analytic Hierarchy Process (FAHP). Analytic Hierarchy Process (AHP) merupakan suatu model pendukung keputusan yang dikembangkan oleh Thomas L. Saaty [21]. Model ini menguraikan masalah multi faktor atau multi kriteria yang kompleks menjadi suatu hirarki. Menurut Saaty [21], hirarki didefinisikan sebagai suatu representasi dari sebuah permasalahan yang kompleks dalam suatu struktur multi level dimana level pertama adalah goal atau tujuan, yang diikuti level faktor, kriteria, sub kriteria, dan seterusnya ke bawah hingga level terakhir dari alternatif. Suatu masalah yang kompleks dapat diuraikan ke dalam unsur-unsurnya yang kemudian diatur menjadi suatu bentuk hirarki sehingga permasalahan tersebut lebih terstruktur. Agar masalah tesebut dapat diselesaikan diperlukan informasi yang relevan. Informasi tersebut dikumpulkan dari narasumber yang terkait dengan masalah yang ingin diputuskan. Pengumpulan informasi dipersiapkan dalam bentuk pengisian kuesioner oleh narasumber dengan menggunakan metode AHP. Pada penelitian ini informasi yang diperlukan adalah penilaian narasumber tentang risiko yang dihadapinya sebagai pelaku rantai pasok minyak kelapa sawit.

Penilaian narasumber terhadap suatu jenis risiko, kriteria ataupun alternatif tidak dapat terlepas dari sisi subyektifnya yang mengandung ketidak-tegasan. Narasumber lebih merasa yakin memberikan penilaian dalam suatu interval dibandingkan dengan penilaian yang tegas (Dagdeviren dan
Yuksel [3]). Dapat juga terjadi bahwa informasi untuk topik yang sama dari daerah yang berbeda akan berbeda pula. Oleh karena itu diperlukan perluasan dari AHP menjadi Fuzzy Analytical Hierarchy Process (FAHP) yang menggunakan cara pengambilan keputusan menggunakan pendekatan logika fuzzy. Logika fuzzy berguna untuk memecahkan permasalahan yang mengandung ketidak-tegasan. Logika fuzzy memungkinkan untuk membangun sistem yang lebih peka mengolah penilaian narasumber yang cenderung sulit menilai secara tegas (Lun dan Leng [13]). Fuzzifikasi adalah proses mengubah bilangan tegas (crisp) menjadi bilangan fuzzy (Zadeh [28]). Menurut Marimin [14], fuzzyfikasi pada metode fuzzy $A H P$ adalah proses pengubahan nilai selang rating (berupa batas nilai) yang diberikan oleh penilai menjadi selang dalam bentuk bilangan fuzzy. Selang rating ini dibuat untuk memfasilitasi ketidakkonsistenan penilai. Sebaliknya, defuzzyfikasi merupakan proses pengubahan kembali output fuzzy ke output yang bernilai tunggal (crisp).

\section{Metode Penelitian}

Sesuai dengan tujuannya penelitian ini terdiri dari dua bagian: (1) Identifikasi risiko para pelaku rantai pasok dan menentukan tingkat kepentingannya, dan (2) Identifikasi strategi peningkatan nilai tambah dan menentukan urutan kepentingannya. Uraian metode penelitian ini disusun sebagai berikut: Pengembangan model, pembuatan struktur hierarki $A H P$, penentuan responden untuk mengisi kuisioner, pengolahan data masukan responden, dan perhitungan skor akhir. Pengolahan data terdiri dari 3 bagian yaitu fuzzifikasi, agregasi dan defuzzifikasi.

\section{Pengembangan Model}

Metodologi untuk kedua bagian penelitian dilaksanakan dengan proses yang sama. Perbedaannya adalah pada jenis data yang diolah. Untuk penelitian identifikasi risiko data yang diolah adalah data-data risiko para pelaku Rantai Pasok Minyak Kelapa Sawit (RPMS). Untuk penelitian strategi peningkatan nilai tambah data yang diolah adalah pendapat para pelaku rantai pasok perihal strategi mana yang seharusnya dipilih.

\section{Struktur Hierarki AHP}

Stuktur hierarki AHP terdiri dari 4 tingkat. Dalam model 1 struktur hierarki terdiri dari fokus/goal, tujuan yang dipertimbangkan, jenis-jenis aktor, dan jenis-jenis risiko. Dalam model 2 struktur hierarki terdiri dari fokus/goal, tujuan yang dipertimbangkan, jenis-jenis aktor, dan pilihan-pilihan strategi peningkatan nilai tambah. Kedua struktur AHP 
tersebut dipergunakan untuk keperluan yang berbeda. Struktur pertama untuk penelitian risiko rantai pasok, sedangkan struktur kedua untuk penelitian strategi peningkatan nilai tambah pelaku rantai pasok.

\section{Responden Penelitian}

Pemilihan responden berdasarkan purposive sampling didapat sebanyak 18 orang mewakili rangkaian ke-enam jenis usaha yaitu petani, pengepul, pabrik $C P O$, pabrik minyak goreng (refinery), distributor, dan konsumen. Oleh karena karakteristik responden sangat heterogen maka data masukan disusun kedalam 3 kelompok yang mewakili 3 rantai pasok minyak sawit yang utuh.

\section{Data Masukan Responden}

\section{Fuzzifikasi}

Nilai fuzzy untuk setiap alternatif didekati dengan Triangular Fuzzy Number (TFN). TFN dipilih oleh karena memiliki nilai keanggotaan penuh yaitu satu yang tunggal pada puncak segitiga untuk nilai batas tengah (BT), sedangkan pada nilai-nilai lain fungsi keanggotaannya lebih kecil dari satu atau nol pada nilai batas bawah (BB) dan batas atas (BA). Dengan demikian maka "keraguan" responden diarahkan kepada "keyakinan" pada di nilai BT. Tiga nilai batas pada skala yaitu BB, BT dan BA dari tiap data masukan mengikuti Kulak dan Kahraman [11] serta Singh dan Sharma [22] (Tabel 1).

Nilai ini digunakan sebagai masukan matriks pairwise comparison. Matriks untuk model 1 disusun untuk pertanyaan-pertanyaan perihal tingkat kepentingan risiko yang dihadapi tiap pelaku dan perbandingan tingkat kepentingan antara satu jenis risiko dengan jenis risiko lainnya. Matriks untuk model 2 disusun berdasarkan tingkat bobot strategi peningkatan nilai tambah rantai pasok minyak kelapa sawit.

\section{Agregasi Masukan Pakar}

Agregasi masukan para pakar yang berbentuk fuzzy dilakukan dengan pembobotan rata-rata untuk batas bawah, batas tengah dan batas atas dari ketiga kelompok masukan (Meixner [15]; Tang dan Beynon [24]). Agregasi ini perlu dilakukan karena adanya tiga kelompok masukan tersebut. Luaran (output) langkah ini masih berupa skor fuzzy.

\section{Defuzzifikasi}

Defuzzifikasi dilakukan untuk menentukan satu nilai crisp dari skor fuzzy. Di sini dipergunakan metode centroid, yaitu nilai tunggal dari variabel output dihitung dengan menemukan nilai variabel dari center of gravity suatu fungsi keanggotaan untuk nilai fuzzy (Meixner [15]).
Tabel 1. Skala konversi fuzzy triangular (Kulak dan Kahraman, [11]; Singh dan Sharma, [22])

\begin{tabular}{lcc}
\hline \multicolumn{1}{c}{ Skala linguistik } & $\begin{array}{c}\text { Skala } \\
\text { fuzzy } \\
\text { TFN }\end{array}$ & $\begin{array}{c}\text { Skala fuzzy } \\
\text { TFN } \\
\text { resiprokal }\end{array}$ \\
\hline $\begin{array}{l}\text { Kedua faktor sama pentingnya } \\
\text { terhadap tujuan }\end{array}$ & $(1,1,3)$ & $(1 / 3,1,1)$ \\
$\begin{array}{l}\text { Satu faktor agak lebih penting } \\
\text { dari yang lain }\end{array}$ & $(1,3,5)$ & $(1 / 5,1 / 3,1)$ \\
$\begin{array}{l}\text { Satu faktor banyak lebih penting } \\
\text { dari yang lain }\end{array}$ & $(3,5,7)$ & $(1 / 7,1 / 5,1 / 3)$ \\
$\begin{array}{l}\text { Satu faktor sangat lebih penting } \\
\text { dari yang lain }\end{array}$ & $(5,7,9)$ & $(1 / 9,1 / 7,1 / 5)$ \\
$\begin{array}{l}\text { Satu faktor mutlak lebih penting } \\
\text { dari yang lain }\end{array}$ & $(7,9,9)$ & $(1 / 9,1 / 9,1 / 7)$ \\
\hline
\end{tabular}

\section{Skor Akhir}

Skor akhir tingkat dan bobot risiko didapat dari hasil perkalian matrix nilai eigen alternatif dengan bobot tiap kriteria. Setelah itu diurutkan menurut nilai tertinggi sampai terendah (Suharjito [23]). Untuk tujuan penelitian (2) dilakukan hal yang sama tetapi dengan masukan data responden untuk strategi peningkatan nilai tambah.

\section{Hasil dan Pembahasan}

Jaringan bisnis rantai pasok kelapa sawit dimulai dari hulu yaitu para petani dan pengusaha kebun sampai ke sisi hilir yaitu pada para pengusaha dan eksportir CPO dan produk turunannya seperti minyak goreng, dan olein. Gambar 2 menunjukkan model jaringan rantai pasok agroindustri kelapa sawit yang sederhana. Untuk makalah ini sisi hilir hanya dibatasi sampai pabrik minyak goreng sebagai produk yang paling dominan dalam rantai pasok kelapa sawit.

\section{Model Identifikasi dan Pembobotan Risiko}

Struktur hirarki AHP untuk melakukan identifikasi dan bobot risiko rantai pasok kelapa sawit ditunjukkan oleh Gambar 3. Dari hasil studi kepustakaan (Muluk dan Hanafi [17], Suharjito [23], Hendra dan Rahardjo [4], Wakker dan Gelder [27]) dan wawancara dengan para pakar dalam industri sawit ditetapkan adanya 3 kriteria pertimbangan dalam penelitian industri sawit yaitu (1) meningkatkan kualitas pasokan untuk tiap pelaku, (2) menjaga kontinuitas pasokan yang stabil, dan (3) menjaga keseimbangan distribusi nilai tambah. Dikenali pula adanya 12 jenis risiko yang dihadapi oleh para pelaku rantai pasok yaitu risiko fluktuasi harga, risiko pasokan yang tidak kontinu, risiko transportasi, risiko bahwa pasar menolak produk yang dihasilkan, risiko produksi tidak lancar, risiko informasi yang salah dan tidak akurat, risiko kualitas bahan dan produk yang tidak memenuhi syarat, risiko penyimpanan dan penggudangan yang tidak memenuhi syarat, risiko tidak jujurnya kemitraan, risiko lingkungan, dan risiko teknologi yang terus semakin bertambah canggih. 


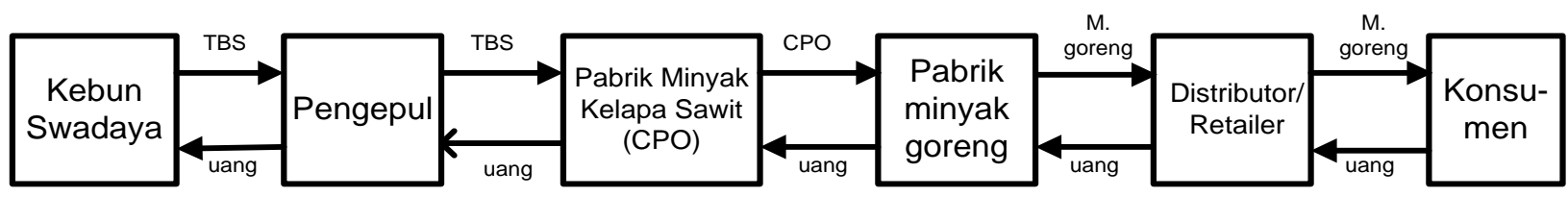

Gambar 2. Jaringan rantai pasok kelapa sawit (Hidayat et al. [5])

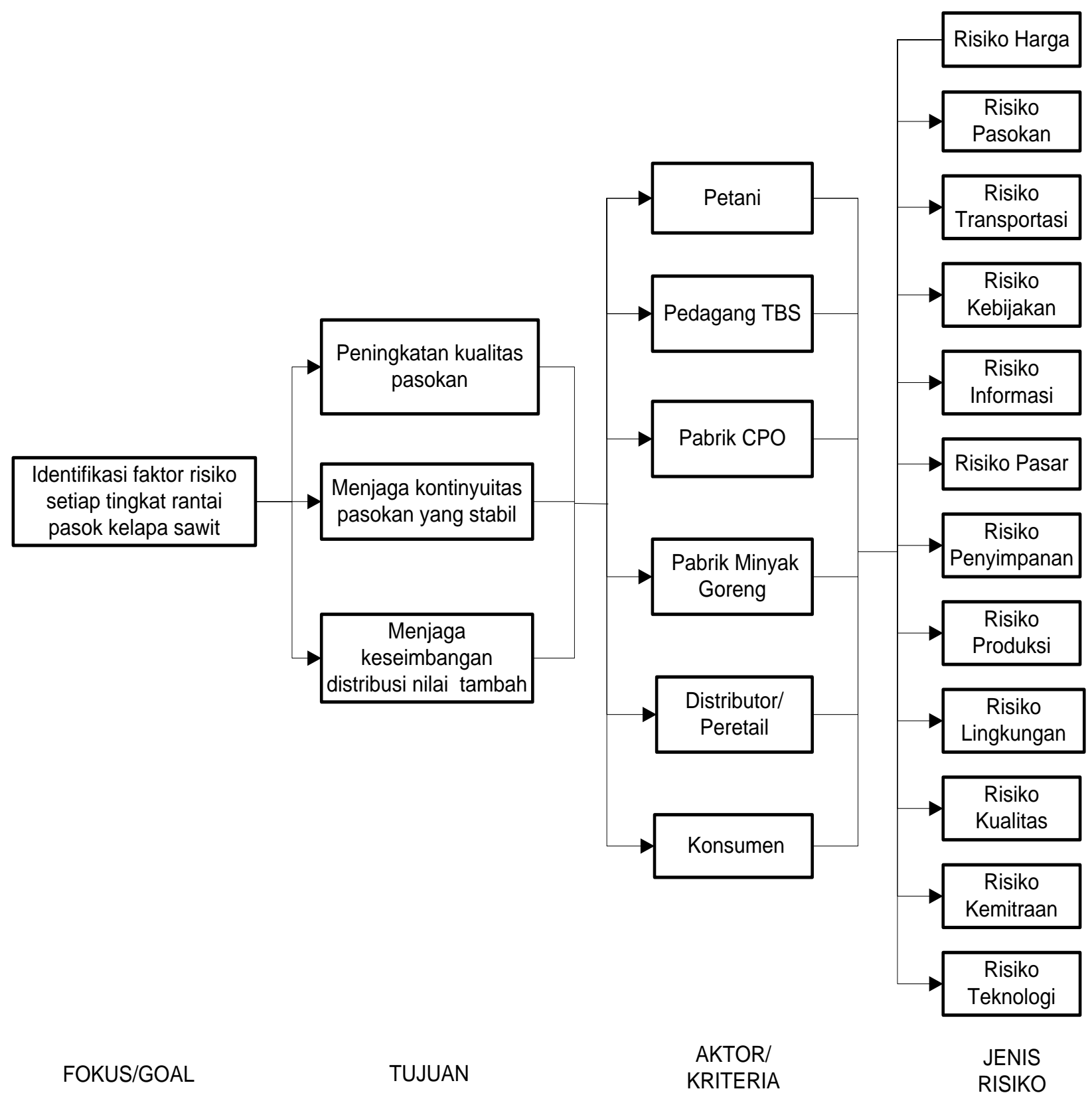

Gambar 3. Struktur hierarki identifikasi tingkat risiko 


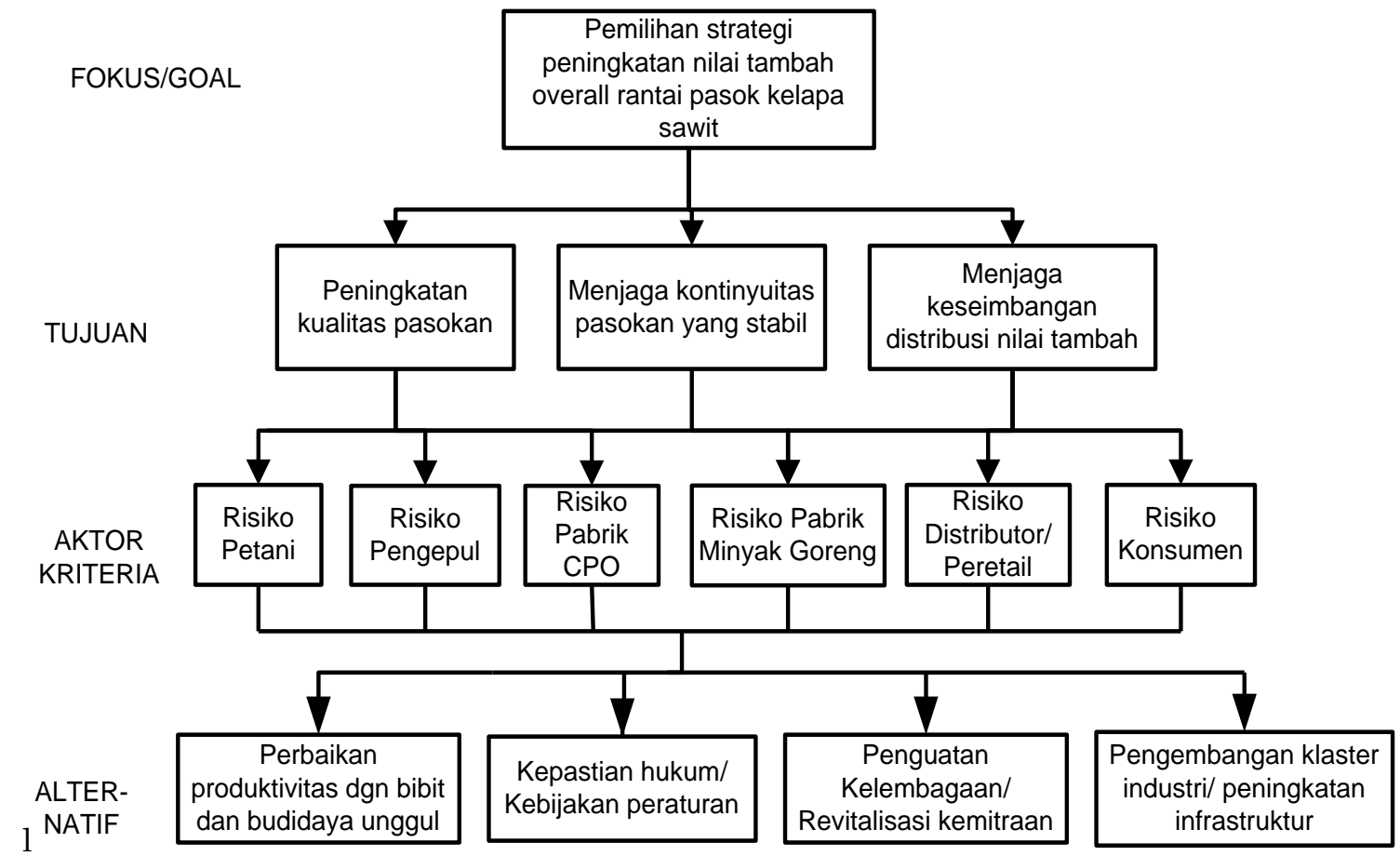

Gambar 4. Struktur hierarki identifikasi strategi peningkatan nilai tambah

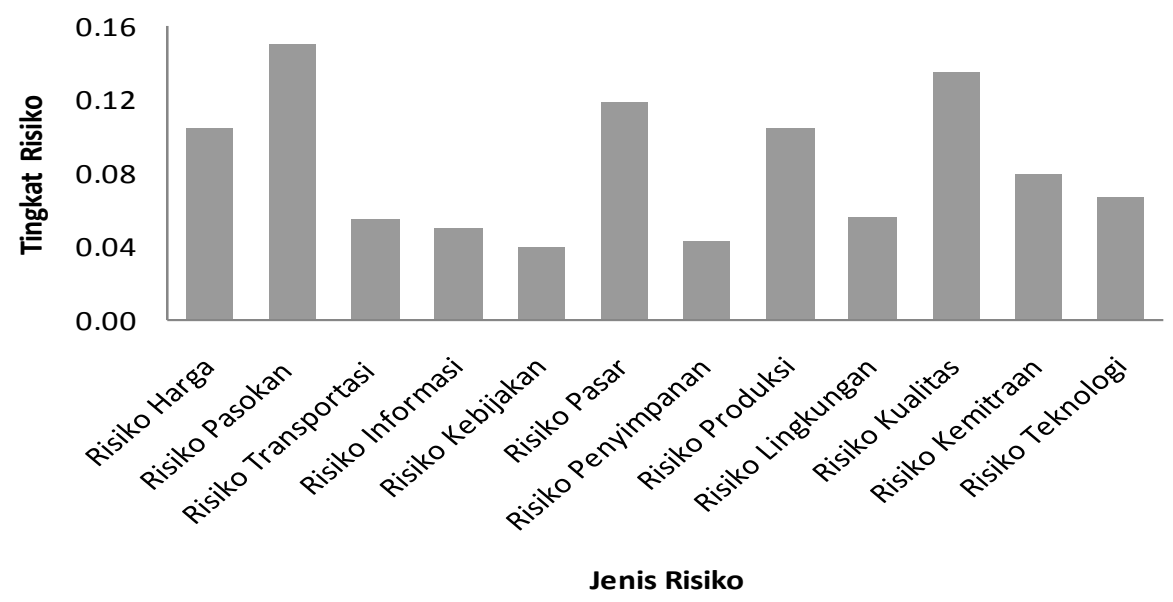

Gambar 5. Histogram bobot tingkat risiko kesatuan rantai pasok kelapa sawit

Tabel 2. Hasil pembobotan risiko tingkatan rantai pasok dengan fuzzy AHP

\begin{tabular}{lcccc}
\hline \multicolumn{1}{c}{ Pelaku } & Kualitas pasokan & Kontinuitas pasokan & Keseimbangan nilai tambah & Tingkat risiko tiap pelaku \\
\hline Petani & 0,36 & 0,30 & 0,30 & 0,31 \\
Pabrik CPO & 0,25 & 0,15 & 0,27 & 0,11 \\
Pengepul & 0,07 & 0,22 & 0,17 & 0,15 \\
Pabrik minyak goreng & 0,20 & 0,11 & 0,08 & 0,15 \\
Distributor & 0,08 & 0,17 & 0,07 & 0,12 \\
Konsumen & 0,05 & 0,04 & 0,05 \\
\hline
\end{tabular}

Tabel 3. Hasil pembobotan strategi peningkatan nilai tambah dengan fuzzy AHP

\begin{tabular}{lrrrrr}
\hline & Petani Pengepul Pabrik PCO Refinery & Distributor Konsumen & Bobot \\
strategi
\end{tabular}




\section{Model Identifikasi dan Pembobotan Strategi Nilai Tambah}

Struktur hirarki $A H P$ untuk melakukan pemilihan strategi peningkatan nilai tambah untuk para pelaku rantai pasok kelapa sawit ditunjukkan oleh Gambar 4. Untuk keperluan ini ditetapkan tiga kriteria pertimbangan yang sama penting yaitu meningkatkan kualitas pasokan untuk tiap pelaku, menjaga kontinuitas pasokan yang stabil, dan menjaga keseimbangan distribusi nilai tambah. Untuk kasus ini dari hasil wawancara para pakar didapat 4 macam strategi untuk peningkatan nilai tambah rantai pasok kelapa sawit: (1) Perbaikan produktivitas dengan bibit dan budidaya unggul, (2) Kepastian hukum/kebijakan peraturan, (3) Penguatan kelembagaan/revitalisasi kemitraan, dan (4) Pengembangan klaster industri/peningkatan infrastruktur.

\section{Verifikasi dan Validasi}

Setelah proses agregasi data selesai dilakukan dan didapat hasil yang masih berbentuk fuzzy maka dilakukan langkah defuzzifikasi untuk mendapatkan nilai tunggal. Metode defuzzyfikasi yang digunakan di sini adalah metode rata-rata geometrik.

Identifikasi risiko tiap pelaku disajikan pada Tabel 2 dengan 3 macam pertimbangan yaitu kualitas pasokan, kontinuitas pasokan dan keseimbangan nilai tambah. Identifikasi ini untuk mengetahui faktor dan variabel risiko yang perlu ditangani oleh tiap pelaku dalam rantai pasok kelapa sawit. Hasil pembobotan faktor risiko menggunakan fuzzy AHP dan selanjutnya nilai bobot risiko tiap aktor hasil proses defuzzifikasi disajikan pada kolom "tingkat risiko tiap pelaku". Urutan bobot risiko pelaku dari tertinggi ke terendah adalah berturut-turut adalah petani, pabrik CPO, pengepul, pabrik minyak goreng, distributor, dan konsumen (lihat Tabel 2).

Hasil defuzzifikasi diperlihatkan pada Gambar 5 . Urutan lima nilai tingkat risiko tertinggi ke terendah adalah berturut-turut (1) Risiko pasokan, (2) Kualitas, (3) Pasar, (4) Harga, dan (5) Kelancaran Produksi, diikuti oleh jenis risiko yang lain. Untuk komoditas jagung (Suharjito [23]) lima nilai tingkat risiko tertinggi adalah (1) Risiko kualitas, (2) Harga, (3) Pasokan, (4) Lingkungan, (5) Pasar.

Berdasarkan model identifikasi risiko terlihat pola sebagai berikut bahwa berdasarkan ketiga pertimbangan yaitu peningkatkan kualitas pasokan untuk tiap pelaku, kontinuitas pasokan yang stabil, dan keseimbangan distribusi nilai tambah, secara konsisten didapatkan tingkat risiko tertinggi pada petani $(0,31)$ sebagai sisi paling hulu pada rantai pasok.
Hal ini dikarenakan risiko kegagalan panen, kesalahan pemilihan bibit, mutu produk yang jelek, buruknya transportasi di areal kebun, kelemahan "bargaining power" dalam menentukan harga merupakan unsur risiko yang tidak bisa dihindari oleh petani. Pengepul $(0,15)$ dan distributor $(0,12)$ sebagai pihak yang mengantarkan bahan atau produk ke tahap berikutnya tidak menderita risiko setinggi petani ataupun produsen yang mengolah bahan menjadi produk baru. Pabrik minyak goreng $(0,15)$ relatif lebih aman karena dapat menyimpan bahan baku lebih lama dibandingkan dengan pabrik CPO $(0,21)$ yang harus secepatnya memproses TBS yang tidak tahan lama disimpan, dan cenderung terpaksa menerima TBS apa adanya dari pengepul/petani.

Untuk komoditas jagung (Suharjito [23]) uruturutan risiko tertinggi adalah untuk petani $(0,54)$, pengepul $(0,16)$, prosesor/pabrik $(0,13)$, distributor $(0,10)$ dan konsumen $(0,08)$. Terlihat bahwa pada kedua jenis komoditas petani menempati tingkat risiko tertinggi. Untuk urutan berikutnya tidak terlihat kesamaan pola antara kedua jenis komoditas.

Data masukan dari para pakar dan narasumber yang diolah dengan metode FAHP memberikan hasil yang hampir konvergen untuk semua pelaku rantai pasok yaitu kelancaran supply, kualitas bahan dan produk, penerimaan pasar, harga yang menarik, dan kelancaran produksi. Dari kelima faktor risiko tersebut ternyata bahwa dua faktor yang sangat penting bagi semua pelaku yaitu kelancaran pasokan kualitas bahan dan produk. Ini berarti bahwa para pelaku akan berusaha sekeraskerasnya untuk mengamankan kelancaran pasokannya dan pengiriman produknya kepada pelanggan, dan mendapatkan bahan serta menghasilkan produk berkualitas unggul. Pentingnya kelancaran pasokan ini sesuai dengan pengamatan Louw et al. [12] pada agro-industri sayur-mayur skala kecil di Afrika; dan laporan MMA [16] pada agro-industri bunga matahari di Tanzania.

Hasil perbandingan bobot strategi peningkatan nilai tambah rantai pasok kelapa sawit ditampilkan pada Tabel 3. Pada kolom terakhir terlihat adanya pilihan yang seimbang antara Perbaikan produktivitas/ penyediaan bahan baku dan bibit unggul $(0,33)$ dan Pengembangan klaster/infrastruktur $(0,33)$. Ini menunjukkan kenyataan bahwa industri kelapa sawit masih sangat memerlukan perbaikan bahan baku dan bibit yang unggul, serta infrastruktur yang mendukung kelancaran pasokannya. Hasil ini sesuai dengan pendapat Louw et al. [12] untuk agroindustri sayur-mayur skala kecil di Afrika; Alam [1] untuk industri sayur-mayur, dan Hitchcock [6] untuk menghadapi kompetisi agroindustri di 
Asia-Pacific. Untuk strategi Kemitraan dan Kelembagaan serta Kepastian hukum/Kebijakan peraturan tampaknya untuk saat ini masih dikalahkan kepentingannya oleh kedua hal pertama tersebut tadi.

\section{Simpulan}

Berdasarkan daftar risiko yang teridentifikasi dapat ketahui tingkat risiko terpenting untuk tiap pelaku maupun untuk seluruh pelaku rantai pasok secara bersama. Dengan demikian maka rantai pasok sebagai kesatuan dapat mengambil langkah yang tepat untuk mengatasi atau menekan dampak buruk risiko-risiko secara bersama.

Unsur-unsur ketidakpastian para pelaku atau aktor rantai pasok yang beragam dapat dipadukan secara harmonis. Para pakar ternyata secara konvergen memilih untuk mengatasi risiko pasokan yang tidak stabil serta memastikan untuk mendapatkan bahan berkualitas dan menghasilkan produk berkualitas.

Pemilihan alternatif strategi peningkatan nilai tambah rantai pasok ternyata konvergen kepada mutlak perlunya pengembangan klaster dan infrastruktur, hal mana mendukung terjadinya pasokan bahan dan aliran produk yang lancar. Pemilihan strategi kepada penggunaan bahan berkualitas dan menggunakan teknik budidaya dan produksi yang unggul akan mendukung terdapatnya bahan dan produk unggulan. Hal ini sejalan dengan hasil yang didapatkan pada bagian pertama yaitu perlunya mengatasi risiko kualitas.

Untuk penelitian lebih lanjut dapat dilakukan identifikasi terperinci perihal langkah-langkah pencegahan dan mitigasi risiko. Selain itu perlu dilakukan perincian strategi peningkatan nilai tambah, yaitu dengan pengembangan klaster/infrastruktur serta peningkatan kualitas bibit dan budidaya yang unggul agar menjadi operasional.

\section{Daftar Pustaka}

1. Alam, A. M., Agri-Exports: Challenges and Prospects, Cab Calling, Programme on Financing Export Oriented Agriculture, Pune, 2006.

2. CAO, Compliance Advisor/Ombudsman, Laporan Audit CAO atas IFC, CAO Compliance, Washington DC, 2009.

3. Dagdeviren, M., and Yüksel, I., Developing a Fuzzy Analytic Hierarchy Process (AHP) Model for Behavior-Based Safety Management, Information Sciences, 178(1), 2008, pp. 1717-1733.

4. Hendra dan Rahardjo, S., Risiko Ergonomi dan Keluhan Musculoskeletal Disorders (MSDs) pada Pekerja Panen Kelapa Sawit, Prosiding
Seminar Nasional Ergonomi IX (C) TI-UNDIP 2009, Semarang, pp. D11.1-D11.9.

5. Hidayat, S., Marimin, Suryani, A., Sukardi dan Yani, M., Modifikasi Metode Hayami untuk Perhitungan Nilai Tambah pada Rantai Pasok Agroindustri Kelapa Sawit, Jurnal Teknologi Industri Pertanian, IPB, Bogor IPB, 22(1), 2012, pp. 22-31.

6. Hitchcock, D. K., Agribusiness and Competitive Agro-Industries in the Asia and Pacific Region, LSFM Regional Forum Workshop and $7^{\text {th }}$ Asia DHRRA GA, Hanoi, 2008.

7. Holton, G. A., Perspective-Defining Risks, Financial Analysts Journal, CFA Institute, 60(6), 2004, pp. 19-25.

8. IRM, The Institute of Risk Management, A Risk Management Standard, The Association of Insurance and Risk Managers (AIRMIC), London, 2002.

9. Janvier-James, A. M., A New Introduction to Supply Chains and Supply Chain Management: Definitions and Theories Perspective, International Business Research Journal, 5(1), 2012, pp. 194-207.

10. Kaplan, S., and Garrick, B. J., On the Quantitative Definition of Risk, Risk Analysis Journal, 1(1), 1981, pp. 1-28.

11. Kulak, O., and Kahraman, C., Fuzzy MultiAttribute Selection among Transportation Companies using Axiomatic Design and Analytic Hierarchy Process, International Journal of Information Sciences, 1(170), 2005, pp. 191-210

12. Louw, A., Vermeulen, H., and Madevu, H., Integrating Small-Scale Fresh Produce Producers into the Mainstream Agri-Food Systems in South Africa: The Case of a Retailer in Venda and Local Farmers, International Conference on Management in AgriFood Chains and Networks, Ede., 2006.

13. Lun, L., and Leng, P. K., Does "Fuzzifying” AHP Improve the Quality of Multi-Attribute Decision Making? Department of Industrial and Systems Engineering, National University of Singapore, Singapore, 2007.

14. Marimin, Aplikasi Teknik Pengambilan Keputusan dalam Manajemen Rantai Pasok, PT Penerbit IPB Press Bogor, 2007.

15. Meixner, O., Fuzzy AHP Group Decision Analysis and Its Application for the Evaluation of Energy Sources, Institute of Marketing and Innovation, University of Natural Resources and Applied Life Sciences, Vienna, Austria, 2009.

16. MMA, Match Maker Associates, Ltd., Value Chain Analysis of Sunflower for the Regions of Morogoro, Iringa, Mbeya and Rukwa, Study Commissioned by ACT - Tanzania Agricultural Partnership, Dar es Salaam, 2010. 
17. Muluk, C., dan Hanafi, I., Rencana Pembangunan Pabrik PKO Kapasitas 400ton/hari di Kawasan Industri Sei Mangkei, Jurnal Transformasi Bisnis, 2(5), 2007, pp. 19-24.

18. Mulyana A., Penetapan Harga Tandan Buah Segar Kelapa Sawit di Sumatera Selatan dari Perspektif Pasar Monopoli Bilateral, Jurusan Sosial Ekonomi Pertanian Fakultas Pertanian dan Program Pascasarjana Universitas Sriwijaya, Palembang, 2004.

19. PKPN, Pusat Kebijakan Pendapatan Negara, Kebijakan Restrukturisasi Tarif Bea Keluar atas Kelapa Sawit, Minyak Sawit dan Produk Turunannya, Badan Kebijakan Fiskal, Kementerian Keuangan, Jakarta, 2011.

20. Preckel, P. V., Gray, A., Boehlje, M., and Kim, S., Risk and Value Chains: Participant Sharing of Risk and Rewards, Journal on Chain and Network Services, 4(1), 2004, pp. 25-32.

21. Saaty, T., Fundamentals of Decision Making and Priority Theory, RWS Publications, Pittsburgh, 1994.

22. Singh, R., and Sharma, S. K., Title-Supplier Selection: Fuzzy-AHP Approach, International Journal of Engineering Science and Technology. 3(10), 2011, pp. 7426-7341

23. Suharjito, Pemodelan Sistem Pendukung Pengambilan Keputusan Cerdas Manajemen Risiko Rantai Pasok Produksi/Komoditi Jagung, Disertasi, Bogor: Sekolah Pascasarjana, Institut Pertanian Bogor, Bogor 2011.
24. Tang, Y. C., and Beynon, M. J., Application and Development of a Fuzzy Analytic Hierarchy Process within a Capital Investment Study, Journal of Economics and Management, 1(2), 2005, pp. 207-230

25. Trienekens, J. H., Agricultural Value Chains in Developing Countries: A Framework for Analysis, Journal of International Food and Agribusiness Management Review, 14(2), 2011, pp. 51-82.

26. Van der Vorst J. G. A. J., Supply Chain Management: Theory and Practices, The Emerging World of Chains \& Networks, Elsevier, Hoofdstuk 2.1, Wageningen, 2004.

27. Wakker, E., and van Gelder, J. W., Assessment of Investment Risks Associated with Environmental and Social Issues Related to an Indofood Sukses Makmur Subsidiary in Rokan Hilir, Riau (Indonesia), Case Study, PT Gunung Mas Raya, PROFUNDO, Amsterdam, 2005.

28. Zadeh, L. A., A Fuzzy-Algorithmic Approach to the Definition of Complex or Imprecise Concepts, International Journal Man-Machine Studies, 8, 1976, pp. 249-291.

29. Zsidisin, G. A., Wagner, S. M., Melnyk, S. A., Ragatz, G. L., and Burns, L. A., Supply Risk Perceptions and Practices: An Exploratory Comparison of German and US supply Management Professionals, International Journal of Technology, Policy and Management, 8(4), 2008, pp. 401-419. 